\title{
Study analysis of landslide vulnerability of mining area in the sub-district Lembah Gumanti, Solok regency (lubuk selasih street- surian)
}

\author{
Momon $^{1}{ }^{*}$, Bayu Martanto Adji ${ }^{2}$, Desi Widia Kusuma ${ }^{1}$, Elsa Yolarita $^{1}$, Vivi Ukhwatu ${ }^{1}$ K Masbiran ${ }^{1}$, and Arian Dodi ${ }^{1}$ \\ ${ }^{1}$ Research and Development Center, West Sumatra Province, Indonesia \\ ${ }^{2}$ Department of Civil Engineering, Andalas University, Indonesia
}

\begin{abstract}
Open access land mining activities on the Lubuk Selasih - Surian national road have in floods and landslides that have, in losses to the community and the imposition of costs for maintenance and rehabilitation of federal roads along the mining area. This study aims to determine the existing condition of mining and analyze the vulnerability of erosions in mining areas. The data used is secondary data, using descriptive quantitative methods with photogrammetric analysis of the maps obtained. The results showed that this mining area has the characteristics of rocks that are easily crushed and tend to be unstable, as well as steep and very steep slopes. This area is also located on the active Semangko fault and volcanic mountains. The environmental carrying capacity of disaster prevention and protection ecosystem services is mainly in the shallow categories. Based on these findings, the mine site is at a very high level of vulnerability to erosions. Thus, it is necessary to mitigate mining management administratively and operationally to minimize environmental damage
\end{abstract}

\section{1 .Introduction}

The mining sector is still very important in supporting the community's economy. However, these mining activities, both near the surface or below the earth's surface, will result in disruption of the landscape and cause significant environmental impacts.

Mining activities on open access lands, which are carried out legally or illegally, in their operations mostly do not follow the rules and carry out their obligations according to what has been outlined and planned. As a result, it will harm the surrounding environment, namely the occurrence of damage and disasters such as sediment flooding and landslides.

According to ESDM (2005), landslides are the movement of slope-forming materials in the form of rocks, debris, soil, or mixed materials, moving down or out of the slope [1]. Landslides often occur due to soil movement in conditions of steep slopes, high humidity levels, and rare plants (open land). Another factor for the occurrence of landslides is seepage and geological activities such as faults, fractures, and linearization. Local environmental conditions are an interrelated component. The shape and slope of the slope, the strength of the material, the position of the groundwater level, and local drainage conditions are also closely related to the condition of slope stability [2]

On the Lubuk Selasih - Surian national road. This condition has been going on for a long time and the incident has been repeated every year, so it has caused considerable losses for the community, national road users, and destination areas such as South Solok Regency and Kerinci Regency and has caused large costs to be incurred for maintenance and repair. rehabilitation of national roads along the mining area. For this reason, it is necessary to identify landslide susceptibility in mining areas to reduce the risks and impacts of mining activities.

This study aims to determine the existing condition of mining, then analyze the vulnerability of landslides on mining land and provide mitigation directions and guidelines in preparing a recovery plan for ex-mining land damage.

\section{Methods}

\subsection{Collecting Data}

The research was carried out in June - July 2021, located in a mining area along the Lubuk Selasih -

\footnotetext{
* Corresponding author: momon.balitbang@sumbarprov.go.id
} 
The research is quantitative. The data used in this study are secondary in the form of area/location, time of occurrence, aerial photography, records of related agencies, land cover maps, geological maps, topographic maps, hydrological maps, maps of environmental carrying capacity, and plate zone map of the mining area in Lembah Gumanti District, Solok Regency.

\subsection{Processing Data}

The map data was obtained from the relevant agencies: the ESDM Office, the SDA \& BK Office[3], the Bina Marga Office[4], the Environment Service[5], BPBD[6], and the Road Implementation Center. An overview of the location is obtained through a literature study of journals and technical documents. The analytical method used is descriptive analysis and overlapping (overlay) using the Geographic Information System (GIS) technology to disaster vulnerability. After overlaying the map, the landslide hazard class interval is made into 4 (four) classes: low, medium, high, and very high. Next, landslide susceptibility is scored based on the criteria: slope, geology, rainfall, infiltration rate, land cover, and fault zone.

Landslide area is determined based on seven variables/criteria determining landslide-prone areas, namely (1) slope, (2) geology, (3) rainfall, (4) infiltration rate, (5) groundwater depth, (6) fault zone (earthquake), and (7) land cover $[7,8,9,10,11,12]$, . Furthermore, to determine the level of vulnerability to landslides at the location of the mine area, it is carried out by weighting each variable according to the level of risk-variable weighting based on professional adjustment and review of previous studies.

Furthermore, to determine the landslide hazard, the researcher used the landslide-prone class interval of the Directorate of Volcanology and Geological Hazard Mitigation (DVMBG) [13]. Landslide Prone Class intervals can be seen in Table 1 below:

Table 1. Landslide Prone Class

\begin{tabular}{|c|c|c|}
\hline $\begin{array}{c}\text { Vulnerability } \\
\text { Class }\end{array}$ & Score & Information \\
\hline 1 & $<1.82$ & Low \\
\hline 2 & $1.82-2.64$ & Currently \\
\hline 3 & $2.64-3.46$ & Tall \\
\hline 4 & $>3.46$ & Very high \\
\hline
\end{tabular}

\section{Results and Discussion}

\subsection{Overview of Research Sites}

Geographically, the landslide area is located in Solok Regency, where Solok Regency is located between 010 $20^{\prime} 27^{\prime \prime}$ to $0102^{\prime} 39^{\prime \prime}$ south latitude to $100025^{\prime} 00^{\prime \prime}$ and 1000 33' 43" east longitude. Solok Regency is one of the regencies in West Sumatra Province, located at an altitude area $30 \mathrm{Km}$ from Padang City (Capital of West Sumatra Province).

The landslide location is on the national road where the only access for South Solok Regency is feasible to take so that if this access is cut off, South Solok Regency will be isolated. There will be a stagnant distribution of commodities or logistics.

Based on the results of the identification of mining areas along the Lubuk Selasih-Surian National Road, Lembah Gumanti District, Solok Regency, there are 7 Mining Business Permits (IUP), namely: PT. Kuansing Mineral Sejahtera, Gunawan Zulmahendra, PT. Cold water sirtu 2, Damiri, CV. PutraYLM, PT. Yuanda Putra YLM and Abdel Hanif.

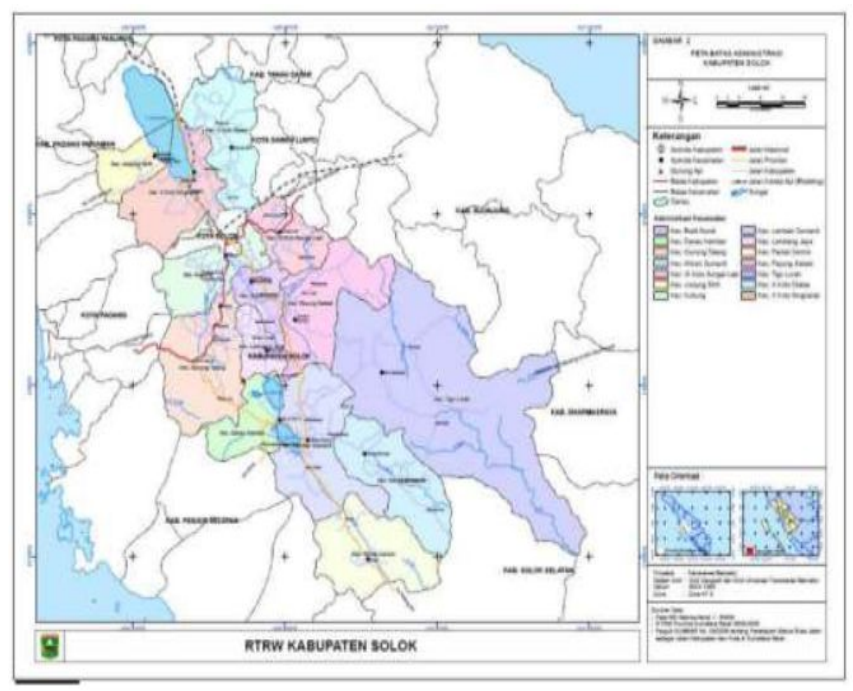

Fig. 1. Solok. District Administration Map

\subsection{Landslide Site Vulnerability Analysis}

\subsubsection{Land Cover Analysis}

The mining area is located in dry fields and sandhills. The area is functionally designated as a mining area (Perda No. 1 of 2013 concerning the RTRW of Solok Regency). However, the area has unstable rocks and has high rainfall, so that the risk of landslides is relatively high.

\subsubsection{Geological Analysis}

Based on data from the Provincial Energy and Mineral Resources Office, the mining area generally has a Barisan Formation $(\mathrm{Pb})$ rock unit consisting of phyllite, slate, limestone, hornstone, and grow to make meta (sandstone). Rock characteristics Mining areas have rock characteristics that are scattered or easily crushed.

As it is known that the location of the mining area is on the active fault line of the Sumatra Great Fault, which causes the rock to be intensely fractured. The fractured rock will respond in the form of crack propagation so that it becomes scattered pieces.

With the characteristics of the rock being scattered, the condition becomes unstable. If there is rainwater, it 
will be quickly eroded by water, resulting in avalanches of material onto the national road.

\subsubsection{Topographical and Morphological Analysis}

To define altitude classes ranging from plains - hills - to mountains, this report uses the following relative altitude classes:

0 - $50 \mathrm{~m}$ : Lowland

$50-200 \mathrm{~m}$ : Low hills

$200-500 \mathrm{~m}: \quad$ Hills

$500-1000 \mathrm{~m}$ : High hills

$>1,000 \mathrm{~m}$ : Mountains

While the slope class to distinguish the surface morphology used the following slope criteria:

Slope (recommended):

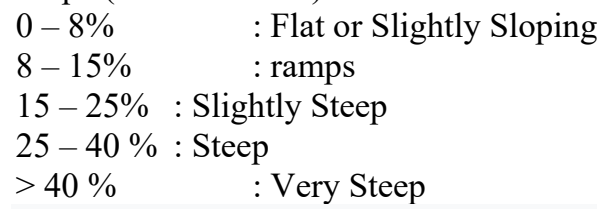

In general, mining areas can be grouped into several morphological units in plains with a slope of $30 \%-70 \%$ (EMR Department, 2020). The elevation in the mining area is generally at an altitude of 1420-1590 masl.

With a steep slope and high rainfall intensity, the material is eroded to the bottom of the valley (river). According to Martono, 2004[14], The steeper and longer slopes will increase the velocity of surface runoff, and the volume of surface water will increase so that more objects can be transported.

According to Kartasapoetra (1990)[15], soil with a slope of $>15 \%$ with high rainfall can cause landslides. Based on the expert's statement, he concluded that the current mining area in cold Aie has a high risk of landslides.

The mining area is in a potential landslide zone. Landslides have often occurred where landslides repeatedly occur four times a year. The flow of water from the top of the cliff is getting harder and harder to control so that it damages the shoulder of the road on the opposite side, which in the long term has the potential to cause the road to be cut off.

In this zone, ground movement can also occur if the rainfall is above standard. Looking at the position of the mining area, it can be concluded that the area generally has a relatively high risk of landslides.

\subsubsection{Hydrological Analysis}

In the mining area, rainfall is included in the very high category ranging from 2,500-3,500 $\mathrm{mm} /$ year, and the mining area is in the upper reaches of the Batang Hari River Basin (6 tributaries of the Batang Hari to the left of the Bt. Hari River), where the catchment area is vast. The Batang Hari tributary ranges from about 13 hectares -97 hectares with a steep slope that can debris flow and landslides.
Discharge simulation if the rainfall intensity is 15 $\mathrm{mm} / 3$ hours; discharge $\mathrm{Q}=3.29 \mathrm{~m} 3 / \mathrm{s}$; if extreme rain > $50 \mathrm{~mm} / 3$ hours; discharge $\mathrm{Q}=10.98 \mathrm{~m} 3 / \mathrm{s}$ with a flow velocity of $5.63 \mathrm{~m} / \mathrm{s}$, the water level in the river is $0.36 \mathrm{~m}$; The velocity of debris flow is very dangerous for the National Road in the mining area which is also an area prone to landslides.

Especially in the Mining Area CV. Putra YLM with an IUP area of 15 ha has changed the natural river flow pattern and impacted bringing sedimentation on the Lb National Road. Selasih - Surian (Landor/Turban Road) still has the potential for erosion where the riverbed is very prone to be eroded again when the intensity of rain is high.

\subsubsection{Environmental carrying capacity and carrying capacity analysis}

The concept of ecosystem services (ecosystem services) can be used to measure the carrying capacity and capacity of the environment. Ecosystem services are grouped into provisioning services, regulating services, cultural services, and supporting services. There is a common understanding between ecosystem services and the carrying capacity and carrying capacity of the environment.

The definition of service provision reflects the concept of environmental carrying capacity and regulatory services, which have similarities with environmental capacity. Meanwhile, supporting services can mean the carrying capacity of the environment and the carrying capacity of the environment. The environment's carrying capacity and capacity with the ecosystem services approach adheres to 2 (two) assumptions. First, the higher the ecosystem services of an area, the higher the ability of the environment to absorb substances, energy, and other components that enter or are included in it (regulatory services). Second, the higher the ecosystem services of an area, the higher the ability of the environment to support human life, other living things, and the balance between the two (providing services, cultural services, and support).

To find out the carrying capacity and capacity of Ecosystem Services for prevention and protection from disasters in mining areas along the Surian-Selasih national road, see Table 2 .

From Table 2, it can be seen that the carrying capacity and carrying capacity of the environment from the aspect of the classification of ecosystem services in the form of prevention and protection from disasters, most of them are in a low category, this indicates that the ability of the environment to protect ecosystem services from disaster prevention and protection is low. Meager means that the potential for disaster is high to very high. The high disaster potential reaches an area of $18.82 \mathrm{Ha}$, while the very high disaster potential is an area of $13.03 \mathrm{Ha}$, located at the Gunawan Zulmahendra mine site, PT. Cold Water Sirtu, CV. YLM's son. 
Table 2. Capacity for Disaster Prevention and Protection Regulatory Services

\begin{tabular}{|c|c|c|c|c|c|c|c|c|}
\hline \multirow{4}{*}{ No. } & \multirow{4}{*}{ IUP name } & \multirow{4}{*}{$\begin{array}{c}\text { IUP } \\
\text { Area } \\
\text { (Ha) }\end{array}$} & \multicolumn{6}{|c|}{ Environmental Carrying Capacity } \\
\hline & & & \multicolumn{6}{|c|}{ Disaster Prevention and Protection Ecosystem Services } \\
\hline & & & \multicolumn{2}{|c|}{ Currently } & \multicolumn{2}{|c|}{ Low } & \multicolumn{2}{|c|}{ Very low } \\
\hline & & & $\mathrm{Ha}$ & $\%$ & $\mathrm{Ha}$ & $\%$ & $\mathrm{Ha}$ & $\%$ \\
\hline 1 & PT. Prosperous Mineral Kuansing & 5.01 & & & & & 5.01 & 38.44 \\
\hline 2 & Gunawan Zulmahendra & 5,10 & - & - & - & - & 5,10 & 39.14 \\
\hline 3 & PT. Cold Water Sirtu & 5.03 & 3.37 & 32.84 & 1.66 & 8.82 & - & - \\
\hline 4 & Damiri & 11.80 & 6.89 & 67.25 & 1.99 & 10.57 & 2.92 & 22.40 \\
\hline 5 & CV. YLM's son & 5.07 & - & - & 5.07 & 26.93 & - & - \\
\hline 6 & PT. Yuanda Putra YLM & 5.01 & - & - & 5.01 & 26.62 & - & - \\
\hline 7 & Abdel Hanif & 5.09 & - & - & 5.09 & 27.04 & - & - \\
\hline & Total & 42.11 & 10.26 & 100 & 18.82 & 100 & 13.03 & 100 \\
\hline
\end{tabular}

\subsection{Fault \& Earthquake Zone}

Tectonically, the position of Solok Regency is included in the Asian continental plate, which is subducted by the Indian Ocean plate on the West Coast of Sumatra. The subduction of the two plates resulted in several active faults on the mainland of Sumatra in the form of the Sumatran Great Fault, known as the Semangko fault.

The mining area location is in a volcanic mountain area. The volcanic mountain area stretches from NorthSouth in the middle of this province, with the Semangko fault in the middle.

The Semangko active fault is the main fault that extends along the Pantai Cermin sub-district, Danau Diatas, Danau Bawah to the north to Lake Singkarak and forms a graben in Solok City, which is part of an active fault along Sumatra. The active fault line in Solok Regency crosses from Pantai Cermin District and continues to the North through Lembah Gumanti District, Lake Diatas - Danau Bawah, Lembang Jaya District, Bukit Sundi District, X Koto Singkarak District and continues to Lake Singkarak. As a result of the movement of the main active fault, other associated active faults with smaller dimensions parallel to the main fault line (Sumatra) spread in Gunung Talang District, Kubung District slightly in Hiliran Gumanti District, Tigo Lurah District, Payung Sekaki District to the north. The main earthquake path in Solok Regency is along the Sumatran fault line that crosses Solok Regency. If there is a release of energy that occurs in the Indian Ocean with a strength of $>7 \mathrm{SR}$, it will potentially produce an earthquake along the fault.

Based on the analysis results above, it illustrates that the mining area is in a landslide Hazard/Prone to Landslide area. This is also reinforced by experts, where according to Arsyad (1989)[16], landslides will occur if the following three conditions are met:

- Slope conditions are steep enough so that the soil mass can move or slide down.

- The condition of the layer below the surface of the soil mass that is somewhat impermeable and soft, which will become the sliding plane.
The condition of sufficient water in the soil so that the layer of soil mass just above the impermeable layer becomes saturated.

According to the Directorate of Environmental Geology (1981), the factors that cause landslides include:

- Topography or steep slope

- condition of soil/rock

- rainfall or water

- Earthquake/earthquake

- State of vegetation/forest and land use

These causal factors influence each other and determine the magnitude and extent of the landslide disaster. The sensitivity of an area to landslides is also determined by the influence and relationship of these factors to one another.

Meanwhile, Djamaluddin (2003) stated that landslide events are three-dimensional (3D) geological phenomena. Landslides (soil movements) in Indonesia generally occur on steep slopes formed from unconsolidated volcanic deposits. Therefore, geomorphological, hydrological, and land cover characteristics can be used as indicators that a landslide has occurred in an area. Steep slopes that are influenced by geological structures such as faults, fractures, folds are more susceptible to landslide symptoms, especially if the direction of rock layers is in the same direction as the slope and there are active faults. Layers of rock that are interspersed between an impermeable rock and water-permeable rock create areas that have the potential as slip fields.

\subsection{Scoring Determination of Vulnerability}

\subsubsection{The basis for Determining Landslide Prone}

The determinants of landslide areas can be divided into two, namely natural and human factors. Natural factors include slope, rainfall, geology, and others, while human factors change natural conditions that result in increased landslide potential.

From the review of these various literatures (see Guillard and Zezere, 2012, Althuwaynee et al., 2012, Akgun et al., 2012, Van Westen et al., 2008, Tejakusuma, 
2007, Gritzner et al., 2001), seven variables were determined. The criteria for determining landslide-prone areas are (1) slope, (2) geology, (3) rainfall, (4) infiltration rate, (5) groundwater depth, (6) fault zone (earthquake), and (7) land cover.

To determine the level of vulnerability to landslides at the mine site, the researchers used several variables by giving each of these variables:

\subsubsection{Landslide Prone Calculation}

Based on the standard for determining the landslide hazard, the calculation of the landslide hazard model is carried out. The calculation of landslide hazard can be seen as follows:

Table 3. Landslide Hazard Scoring Results

\begin{tabular}{|c|c|c|c|c|}
\hline No & Criteria & Score & Weight & Score \\
\hline 1 & Slope & 5 & $30 \%$ & 1.5 \\
\hline 2 & Geology & 5 & $20 \%$ & 1 \\
\hline 3 & Rainfall & 4 & $20 \%$ & 0.8 \\
\hline 4 & Infiltration Rate & 4 & $10 \%$ & 0.4 \\
\hline 5 & Land Cover & 5 & $10 \%$ & 0.5 \\
\hline 6 & Fault Zone & 5 & $10 \%$ & 0.5 \\
\hline \multicolumn{2}{|c|}{ Amount } & & $100 \%$ & 4.7 \\
\hline
\end{tabular}

Referring to the calculation results of Landslide potential and Landslide Prone Class Interval, the location of the mining area is currently at very high Landslide Hazard. For this reason, it is necessary to direct mitigation from stakeholders related to landslide prevention to reduce the occurrence of landslides.

\subsubsection{Administrative and Operational Violations}

In addition to the very high vulnerability to landslides, on the other hand, there are also violations of administration and operations in mining management.

Then the company's compliance with administrative and operational order for the management of the mining area is a must; this is a form of synergy from the government and company elements so that the implementation of mining activities can be monitored and by Standard Operating Procedures (SOP).

With the landslide disaster caused by mining activities, the Mining Inspector of the Ministry of Energy and Mineral Resources of the Republic of Indonesia has examined the completeness of the mining company's documents as well as the examination of violations of technical and environmental aspects.

\subsection{Landslide Disaster Mitigation Directions}

From the analysis results, it is necessary to mitigate landslides to cope with more severe damage. The directives for disaster mitigation that can be carried out on post-mining land partially or for mining land closure as a whole are as follows:

\subsubsection{Land Arrangement}

The form of land arrangement can be suggested as follows:
1. Reconstruction of Land Forms (Reshaping)

- Reconstruction of landforms is carried out to obtain stable slopes with low potential for landslides and erosion and is suitable for revegetation. Reconstruction of landforms at exmining sites with irregular and uneven landforms (perforated, with relatively steep slopes) must be arranged in such a way as to be stable with low potential for landslides and erosion. Existing piles of material are disposed of or used for filling existing holes by taking into account the characteristics of the materials used for backfilling and the presence or absence of a drainage system that may be disrupted.

- Reconstruction of the shape of the slope is carried out to reduce the speed of runoff, erosion, sedimentation, and landslides. The shape of the slopes in this mining area is relatively steep with a significant height difference, so it is necessary to build terraces. For each terrace formed, it is necessary to make a terrace channel so that it can drain the water in the terrace area in a controlled manner.

2. Construction of Drainage Channels

Construction of drainage channels aims to prevent excessive rainwater inundation and drain surface runoff so that excess water is planned to flow quietly and not damage the soil surface, plants, and other soil conservation structures. The drainage channels that need to be made consist of:

a)evasion channel

An evasion channel is made to cut off runoff from the area or plot of land above the slope so that it does not enter the surrounding area so that runoff and erosion are reduced. The evasion channel is made to cut the slope at a slight angle $(0.1-0.5 \%)$ with the contour line to allow water to flow. When digging the channel, the 
excavated soil (fill) is used to make mounds or embankments on the lower side.

Before entering the sewer, making sediment settling pond (sediment pond) is necessary to settle the sediment particles carried by the water flow.

b)Drainage.

The drainage channel (SPA) removes water from the ex-mining area that previously flowed in the evasion channel or terrace channel. The existence of this drainage channel is necessary so that the water collected in the evasion channel or terrace channel can be drained out in a controlled manner so that it is not destructive. The presence of a sewer will cut the escape channel or terrace with varying spacing (distance between SPAs) c)Plunge depending on field conditions.

A plunge needs to be made that reduces the velocity of surface runoff so that the water flows at a speed that is not destructive and does not carry large amounts of sediment.

\subsubsection{Erosion And Sedimentation Control}

This ex-mining land consists of loose material (pile), which is easily eroded. Therefore, efforts to control erosion and sedimentation need to be continued. Methods that can be done are:

1. Vegetative Method

It is carried out using cover crops, and revegetation is part of the recovery activity, which also controls erosion and sedimentation. Ground cover plants are plants intended to cover the soil so that raindrops do not directly hit the soil. Cover crops can be planted alone or planted together with main crops. Another function that is expected from cover crops is to provide organic matter to maintain soil fertility.

2. Mechanical Method

It is carried out in locations with serious erosion problems that are not possible if only vegetative erosion control is carried out. Several mechanical methods that can be applied are terracing, evasion channels, and control dams (Sabodam/check dam).

a. Terrace/Terrace

In very steep areas such as mining areas, bench terraces are recommended to reduce runoff and erosion more effectively.

b. Diversion Ditch

In the case of trench erosion or gully erosion, a diversion channel can be made to control it. A ditch is made on the upper slope of the area affected by ditch erosion or ravine erosion. The entry of water flow into the ditch or ravine can be prevented so that ditch erosion or ravine erosion does not continue. The end of the evasion channel is directed to a part of the land that is still densely overgrown with plants or to a safe SPA, namely a SPA overgrown with grass.

c. Control Dam (Sabo Dam)
In locations where trench erosion occurs due to concentrated water flow, it is necessary to build a control dam that functions as a reservoir for water and sediment. The specifications of the control dam depend on the magnitude of the erosion of the trench. If the trench is significant enough (ravine erosion), where the surface runoff is large enough, then a permanent concrete control dam (Sabo Dam) is the best alternative.

\subsubsection{Water Quality Management}

The process of mining rock mining materials at the mine site is carried out by digging the material and then separating the desired material by a washing process using water. The material transported in the effluent is finesized particles. The particles in the effluent will settle according to the law of gravity, with a particular retention time. Therefore, the problem of water quality in this exrock mining area is the level of turbidity. To overcome this, it is necessary to make settling ponds with dimensions tailored to the needs. Settlement ponds are made with a zigzag model so that the suspended particles have sufficient time to settle. In particular, conditions where the TSS value exceeds environmental quality standards, coagulant materials such as alum, cationic polymers,

\subsubsection{Management of Domestic Waste and Hazardous Toxic Waste (B3)}

Mining activities cause a large amount of solid waste to accumulate in the form of organic and inorganic waste originating from the mess, kitchen, canteen, and office activities, including Hazardous and Toxic Material (B3) waste. Organic and inorganic solid waste (plastic and the like) is disposed of at the TPS to minimize it.

In addition, mining activities that use heavy equipment will produce B3 waste in used oil, used diesel, grease, and spilled fuel. To minimize the impact of waste oil/lubricant and used diesel fuel, environmental management is carried out through;

1) Oil/lubricant, grease, and used diesel fuel are packed carefully in a unique drum, then collected in the temporary shelter provided.

2) To reduce the impact of used oil spills, using diesel fuel, and others in the workshop area and fuel station, an oil trap is created, where the oil trap is separated between the oil layer and the water layer so that both can be taken separately, then transferred to the drum that has been provided and collected to the B3 waste collection site in the appropriate workshop Government Regulation No. 101 the year 2014 regarding Management of Hazardous and Toxic Waste (B3)

3) Conduct temporary bioremediation to anticipate the spilled B3 waste. 


\subsubsection{Waste Material Stack Management}

Mining activities leave large puddles in former mining sites and produce residual material that accumulates in various locations. The step taken is leveling the land using heavy equipment so that it does not have holes and becomes flat. Furthermore, land cover is carried out with organic materials from plant remains such as straw, grass, vegetables. In addition, backfilling is also carried out with particular soil for locations that are planned to be planted with plants.

\subsubsection{Reclamation of Ex-Mining Land}

To restore land that has been disturbed due to mining activities, the government requires mining actors to carry out land reclamation or restoration, as stated in Law no. 4/2009 concerning Mineral and Coal Mining, Law no. 41/1999 on Forestry, Law no. 32/2009 concerning Environmental Protection and Management, and their respective derivatives. Recovery/reclamation of exmining land is intended to obtain land conditions that are safe, stable, and not easily eroded so that it can be reused according to its designation.

The implementation of the restoration of damaged exmining land must comply with the principles of environmental protection and management, which include:

- Protection of the quality of surface water, groundwater, seawater, soil quality, and air quality based on environmental damage criteria under the provisions of laws and regulations.

- Protection and restoration of biodiversity.

- Guarantee the stability and safety of overburdened piles, tailings ponds, ex-mining land, and other artificial structures.

- Utilization of ex-mining land under its designation.

- Pay attention to the social, economic, and cultural conditions of the local community.

Utilization of ex-mining land that has been arranged can be in the form of revegetation with forestry plants, plantation crops, food crops as a source of water if there are ex-dug holes with good water quality.

Determination of the type of land use, whether for food crops, plantations, agro-tourism, or others, needs to be based on, among other things, the status of ownership and the biophysical condition of the land as well as the needs of the community.

\subsubsection{Revegetation with Forestry Plants}

Revegetation activities are carried out through the following stages:

1. Field Preparation

Lands laid out and have drainage channels made need to be well prepared before planting with pioneer plants or other types of plants. In general, field preparation includes planting cover crops, determining the direction of the array and installing stakes, and making plant holes.
2. Procurement of Seeds

Seeds to be planted can be produced at the nursery/nursery or through purchase. Seedlings that are made or purchased are seeds that have quality and nutritional standards. In addition, the seeds produced and purchased are seeds suitable for planting in the area. Therefore, the selection of species to be planted must be carried out. The choice of species must consider the ecological suitability of the place where it grows. The suitability of ecologically appropriate tree species for planting in land restoration areas can be determined by: i) taking an inventory of native tree species, ii) conducting species site matching through literature studies and analysis of the suitability of growing conditions, and iii) conducting a species trial or other crop testing.

3. Planting Implementation

Planting is carried out after land preparation is complete and at the beginning of the rainy season. Healthy seedlings with a minimum height of $50 \mathrm{~cm}$ are transported carefully from the nursery/nursery to the planting site. The seeds are then placed near the prepared planting holes. When planting, the compost that has been inserted into the planting hole is mixed with topsoil. Then the polybag is carefully opened first so that the media remains intact, then the seeds are inserted into the planting hole and backfilled with soil up to the height of the root neck. Seedlings that have been planted are marked with a stake that is plugged near the seedling.

\subsubsection{Revegetation With Plantations And Food Crops}

Revegetation with plantation crops and food crops is similar to revegetation with forest crops. The difference between the two is more to the type of plant selected. Plantation crops that can be selected are rubber, cocoa, coffee, and others, while food crops such as corn, cassava, sweet potato, and others.

If the use of ex-mining land is carried out through revegetation, then improving the quality of the soil, as discussed in the previous chapter, becomes very important to do. Another thing that needs to be considered besides the quality of the soil as a planting medium is climatic conditions. Soil quality and climatic conditions will determine the success rate of land restoration.

Soil health is also an essential factor, mainly if land restoration is used for planting food crops. Not all exmining areas are dangerous from the food safety aspect. However, some of them need to be considered, mainly if the geochemical aspect of the extraction method of mining materials produces or uses harmful compounds to the environment.

\subsubsection{Maintenance and Monitoring}

Maintenance and monitoring are activities carried out after land management and revegetation activities have been completed to ensure that the results of land restoration are as expected. Maintenance includes plant 
maintenance activities and maintenance of the physical condition of the field. Monitoring needs to be carried out periodically until finally all the land that has been restored is judged to have been successful.

\section{Conclusion}

Based on the description in the previous chapter, it can be concluded as follows:

1. Mining areas are in rocky characteristics that are scattered or easily destroyed. Conditions will reach instability if there is high enough rainfall, causing landslides.

2. With a steep or very steep slope, the velocity of runoff will increase, and the volume of surface water will increase, resulting in a high risk of landslides. Then the location of the mine site, which is upstream of the Batang Hari River Basin, has the potential to experience debris flow.

3. Most of the Ecosystem services in the form of prevention and protection from disasters are in the low/deficient category, so the potential for disaster is high to very high.

4. The mining area is in the Landslide Hazard/Prone to Landslide area because it is located on the active Semangko Fault and volcanic mountain area.

5. The results of the calculation of the potential for landslides show the mining area Landslide Hazard is very high, so it needs mitigation to reduce damage to the surrounding environment.

6. There are violations in mine management, both administrative and operational, including administrative aspects, operational aspects, mining technical aspects, environmental protection aspects, conservation aspects, health and safety aspects, and aspects of standardization and mining services business.

Thank you to all parties who helped in the research process.

\section{References}

1. Mineral Resources Energy. Introduction to the Land Movement, Vulcanological Survey of Indonesia. Mineral Resources Energy. Jakarta. (2005)

2. C Fandeli, Z Zakaria, Slope Analysis. Unpad. Bandung. (2000)
3. Department of Natural Resources Of West Sumatra Province, Mapping Of River Flow Areas, (2021) (Unpublished).

4. Ministry Of Public Works And Spatial Planning, Republic Of Indonesia

5. West Sumatra Provincial Environmental Office, Capacity And Regional Sustainability, (2021).

6. Department of Energy and Mineral Resources, Geological Map (2021).

7. Regional Disaster Management Agency Of West Sumatra Province, Disaster Location Data, (2021).

8. C Guillard, J Zezere, Landslide Susceptibility Assessment And Validation In The Framework Of Municipal Planning In Portugal: The Case Of Lourses Municipility. Environmental Management, (2012)

9. O. F. Althuwaynee, B Pradhan, \& S. Lee, Application Of An Evidential Belief Function Model In Landslide Susceptibility Mapping. Computers \& Geosciences, 44, 120-135, (2012)

10. A. Akgun, C. Kineal, \& B. Pradhan, Application Of Remote Sensing Data And Gis For Landslide Risk Assessment As An Environmental Threat To Izmir City (West Turkey). Environ Monit Assess, 184, 5453-5470. (2012)

11. C. J. Van Westen, E. Castellanos, \& S. L. Kuriakose, Spatial Data For Landslide Susceptibility, Hazard, And Vulnerability Assessment: An Overview. Engineering Geology Journal, 102, 112-131, (2008)

12. I. G. Tejakusuma, Threat of landslides. Natural, 12, 72-75, (2007)

13. M. L. G Gritzner, W. A Marcus, R. Aspinal, \& S. G. Custer, Potential Landslide Assessment Using Gis, Soil Wetness Modelling And Topographic Attributes, Payette River, Idaho. Geomophology, 37, 149-165, (2001)

14. Directorate of Volcanology And Geological Hazard Mitigation, Determine The Landslidehazard, Jakarta, (2005)

15. Martono. (Effect of Rain Intensity and Slope Slope on Soil Loss Rate in Gray Regosol Soil. Thesis. Diponegoro University, Semarang), (2004)

16. A. G. Kartasapoetra, (Damage to Agricultural Land and Efforts to Rehabilitate It.) Bina Aksara, Jakarta, (1990)

17. S. Arsyad. (Soiland Water Conservation). Ipb Press. Bogor (1989) 